\title{
The Clinical and Economic Value of Triclosan-Coated Surgical Sutures in Abdominal Surgery
}

\author{
Marco Ceresoli ${ }^{1}$ (1), Francesca Carissimi ${ }^{1}$, Alessandra Piemontese ${ }^{2}$, Vito Paragò ${ }^{2}$, \\ Thibaut Galvain ${ }^{3}$ (D), Giovanni A. Tommaselli ${ }^{2}$ and Luca Gianotti ${ }^{1, *(D)}$ \\ 1 School of Medicine and Surgery, Milano-Bicocca University and Department of Surgery, San Gerardo \\ Hospital, 20900 Monza, Italy; m.ceresoli4@campus.unimib.it (M.C.); f.carissimi@campus.unimib.it (F.C.) \\ 2 Johnson \& Johnson Medical SpA, 00071 Pomezia, Italy; apiemont@its.jnj.com (A.P.); \\ vparago@its.jnj.com (V.P.); gtommase@its.jnj.com (G.A.T.) \\ 3 Johnson \& Johnson Medical SAS, 97132 Issy-les-Moulineaux, France; tgalvain@its.jnj.com \\ * Correspondence: luca.gianotti@unimib.it; Tel.: +39-039-2332391
}

Received: 11 December 2019; Accepted: 30 January 2020; Published: 6 February 2020

\begin{abstract}
Surgical site infection (SSI) is a frequent complication of surgical procedures. The aim of this study was to analyze the clinical evidence for SSI prevention with triclosan-coated sutures (TCS) in abdominal surgery and to investigate the economic impact of TCS in this type of procedure compared with conventional absorbable sutures (CS). A literature review was carried out to identify meta-analyses that were published between 1990 and 2019 that assessed the use of TCS in abdominal surgery. A budget impact analysis was performed from an Italian hospital perspective based on the most recently published evidence to simulate the financial impact of TCS in a general surgery unit. Uncertainty was explored through scenario analysis, as well as deterministic and probabilistic sensitivity analyses. Nine meta-analyses and two additional randomized clinical trials were retrieved. All meta-analyses described a reduction (range 19\%-44\%) in the risk of SSI when TCS were used. The use of TCS was associated with an overall annual net saving for the general surgery unit of $€ 14,785$ and a reduction of 3.2 SSIs compared with CS. Sensitivity analyses resulted in a positive annual saving associated with TCS in $98 \%$ of scenarios. TCS are a valuable, cost-saving SSI prevention strategy. TCS additional costs would be offset by the reduction in SSIs.
\end{abstract}

Keywords: triclosan; surgical site infection; suture; abdominal surgery; cost-analysis; budget impact analysis

\section{Introduction}

A surgical site infection (SSI) is defined as an infection that occurs within 30 days of surgery if no implant is left in place or within 90 days if an implant is left in place [1]. According to the World Health Organization (WHO) definition, SSIs may involve skin and subcutaneous tissue (superficial incisional), the deep soft tissue of the incision such as fascia or muscle (deep incisional), and/or any part of the body other than the incision that was opened or manipulated during an operation (organ/space) [1].

Despite established preventive measures [2], SSI remains the most frequent complication following abdominal surgery—defined as any surgical procedure on the abdominal cavity followed by abdominal wall closure-with an incidence rate of $10 \%-20 \%$ in contaminated and dirty surgery [3]. SSI is not only a surgical complication that affects the length of stay, it also has a significant impact on the patient's perceived quality of life. Moreover, SSI is an important risk factor for readmission, reintervention, and the development of incisional hernia [4,5], resulting in increased healthcare-related costs [6]. Postoperative infectious complications also negatively affect long-term outcomes [7,8]. 
The pathogenesis of SSI is multifactorial. The main patient-related risk factors for SSIs include active smoking, impaired nutritional status, obesity, immune deficits, and diabetes, while surgery-related risk factors include the degree of field contamination, the duration of surgery, hypothermia in the operating room, and the colonization of bacterial biofilm on sutures [9-13]. To help reduce the risk of SSI, sutures coated with antimicrobial materials have been introduced in clinical practice. The most common antibacterial agent that is used to coat sutures is triclosan, which offers broad-spectrum bactericidal action against Gram-positive and Gram-negative bacteria [14]. In both in vitro and in vivo studies, microorganisms that are responsible for SSIs were prevented from binding to and colonizing triclosan-coated sutures (TCS), with the action lasting roughly 30 days from the implantation of these sutures $[15,16]$.

Guidelines, including those issued by the US Center for Disease Control (CDC), WHO, the American College of Surgeons (ACS), and National Institute for Health and clinical Excellence (NICE), recommend the use of TCS for the prevention of SSIs [16-19].

Several randomized clinical trials have investigated the efficacy of TCS in reducing SSI following abdominal surgery; some have established a positive effect of TCS, whereas others have failed to demonstrate statistically significant differences versus conventional absorbable sutures (CS) [20-27]. Recent meta-analyses reported a significant effect, or at least a positive trend, in favor of TCS over CS in reducing SSI rates following abdominal surgery [28,29]. The partial disagreement between the meta-analyses results is likely attributable to differences in the number of studies included, the degree of field contamination (CDC classification of the wounds), the heterogeneity of surgical procedures considered, and the inclusion of trials with low-level evidence, all of which introduced uncertainty in the overall interpretation of results.

The purpose of this study was to critically analyze and appraise the latest available evidence on the role of TCS on SSI prevention in a more homogeneous population represented by patients undergoing abdominal surgery. A literature review of meta-analyses that considered TCS in abdominal surgery was conducted, and a cost analysis was subsequently performed to investigate the economic impact of TCS to provide a more comprehensive representation of the value of this technology in clinical practice.

\section{Materials and Methods}

\subsection{Literature Review}

\subsubsection{Criteria for Considering Studies for Literature Review}

Types of studies: Meta-analyses including randomized controlled trials (RCTs), RCTs not included in the meta-analyses, and systematic reviews with the target intervention (TCS) in one arm and in abdominal surgery were included. The endpoints included measures of TCS efficacy on SSI. Meta-analyses not including abdominal procedures or not performing a sub-analysis for abdominal procedures were excluded.

Types of participants: The review included adult patients undergoing abdominal surgery where TCS was considered to be an option to approximate any of the soft tissue layer of the surgical wound.

Types of interventions: The target intervention was the use of TCS to approximate any soft tissue layer(s) in abdominal procedures. The comparator intervention was the use of CS.

Types of outcome measures: Outcomes had to be quantitative and reported either on an intention-to-treat or per protocol basis in the respective studies. Compilations and comments were excluded. The primary endpoint was defined as overall SSI rates. SSI was defined according to the CDC criteria [1]. 


\subsubsection{Search Methods for Identification of Studies}

The electronic databases PubMed (MEDLINE), Scopus, Ovid, Institute for Scientific Information Web of Science, and the Cochrane Central Register of Controlled Trials and Cochrane Library database (CENTRAL, CDRS, NHSEED and HTA) were searched from January 1990 to June 2019.

The search strategy used the following syntax: (plus OR antimicrobial OR triclosan) AND (abdominal OR intestinal OR bowel OR gastrointestinal) AND (suture OR sutures) AND ([literature AND review] OR meta-analysis OR meta-analysis OR [meta AND analysis]) AND (infection) AND "humans" [MeSH Terms]. No geographic limits were applied, and only articles in English were considered.

The reference list for each literature review was examined for missing studies within the scope of this review.

\subsubsection{Study Selection}

Following the removal of duplicate references, two reviewers (M.C. and F.C.) independently assessed the eligibility of each of the remaining pre-selected references by screening the titles, keywords and abstracts according to the systematic review eligibility criteria. The reviewers subsequently and independently assessed the full texts of all potentially relevant references for their eligibility. Following selection, discrepancies between the reviewers were resolved by discussion, and, when a consensus could not be reached, a final decision was taken by majority after consultation with the senior reviewer (L.G.). Multiple publications reporting on the same study were jointly analyzed as reporting one study. Reference lists of full-text articles were hand-searched to identify relevant publications that were missed.

The inclusion criteria for study selection were systematic reviews and meta-analyses including only RCTs investigating the role of TCS in abdominal surgery. We also searched for additional RCTs that were not included in the meta-analyses published between January 2013 and June 2019. The exclusion criteria were meta-analyses of studies that investigated operations other than, or not only, abdominal surgery, as well as observational studies. The most recently available meta-analysis that fulfilled the selection criteria was then critically appraised. The Appendix A table reports the list of all other published meta-analyses on TCS that were excluded from this study since they were not in line with the above-mentioned inclusion criteria.

\subsubsection{Data Extraction and Management}

Data extraction was performed in a standard electronic spreadsheet, with the reviewers independently extracting the data from all eligible articles. Extractions were compared and disagreements resolved by discussion or by consultation with a third reviewer. The following data and information were extracted: year of publication, number of studies included, number of patients included in the two groups, and outcome measurements (overall SSI risk including relative risks (RR), odds ratios (OR), 95\% confidence intervals (CI), and all possible sources of bias).

\subsection{Budget Impact Model}

The economic model was developed in Microsoft ${ }^{\circledR}$ Excel and used to perform a budget impact analysis in accordance with the International Society for Pharmacoeconomics and Outcomes Research (ISPOR) guidelines "Principles of Good Practice for Budget Impact Analysis" [30,31]. This analysis evaluated the impact of introducing TCS as an alternative to conventional sutures (CS), for the prevention of SSIs from an Italian hospital perspective, and more specifically from a general surgery unit. The model compared the incremental cost of adopting the technology with the potential savings derived from the reduction of SSI incidence on the total number of performed abdominal procedures. The model output consisted of a net potential saving for the surgery that was achievable by a total conversion from CS to TCS and a reduction of SSI episodes. 


\subsubsection{Model Inputs}

The model included the following inputs: baseline SSI rate, SSI reduction, the additional cost of TCS over CS, the number of sutures used per procedure, and the cost of SSI. The baseline SSI rate was taken from an Italian trial that reported the SSI rate in 281 patients undergoing colorectal resection as equal to $10.6 \%$ [23]. SSI reduction, attributable to implementing TCS into clinical practice, was selected from the reviewed meta-analysis as previously described. The differential cost of sutures was assumed to be an additional $€ 1$ for TCS compared with CS. According to expert opinion, six absorbable sutures are required per abdominal procedure, with 600 sutures used when assuming that 100 procedures are performed annually. The cost of a single SSI episode was taken from an Italian study, published in 2000 , that evaluated the hospital resources that are consumed to treat postoperative infections among patients with gastrointestinal cancer who underwent abdominal procedures [32]. The cost that was identified for each wound infection was inflated to 2019 costs according to the Italian Institute of Statistics Consumer Price Index of 1.296. An SSI cost-specific for an abdominal surgery and referred to the Italian environment-of $€ 4,838$ was therefore considered in this economic analysis. The cost breakdown was attributed to additional resource use (14\%) and prolonged length of stay (LOS) (86\%), as previously described [32].

\subsubsection{Scenario and Sensitivity Analyses}

To assess the robustness of the primary analysis, scenario and sensitivity analyses were conducted from the Italian hospital perspective (general surgery unit). In the scenario analyses, the model assumed different scenarios from the base case according to the SSI risk reduction: 1) The SSI reduction rate was set at the lower bound of the $\mathrm{CI}$, and 2) the SSI reduction rate was set at the upper bound of the CI. Uncertainties surrounding model parameters were also assessed through one-way sensitivity analyses that varied key parameters by using the $95 \%$ CIs where possible or by applying a $\pm 25 \%$ range of variation. The considered parameters included the baseline SSI rate, the cost of a single SSI, the number of sutures used per surgical procedure, and the SSI reduction rate. Furthermore, a probabilistic sensitivity analysis (PSA) was performed in which the above parameters were simultaneously varied by randomly sampling these values from the distribution assigned for each parameter for 1000 iterations. Distributions used for each parameter are presented in Table 1.

Table 1. Parameters and respective distributions considered in the probabilistic sensitivity analysis.

\begin{tabular}{ccccc}
\hline PSA Parameters & Base Case Value & Lower Range & Upper Range & Distribution \\
\hline Baseline SSI rate & $10.6 \%$ & $6.1 \%$ & $16.2 \%$ & Beta \\
Cost of SSI & $€ 4838$ & $€ 4355$ & $€ 5321$ & Gamma \\
Number of sutures per procedure & 6 & 4.5 & 7.5 & Gamma \\
SSI reduction rate (relative risk) & 0.70 & 0.49 & 0.98 & Log-normal \\
\hline
\end{tabular}

Abbreviations: SSI, surgical site infection.

\section{Results}

\subsection{Clinical Results}

Nine meta-analyses were identified from database searching [28,29,33-39] (Table 2). After the critical appraisal of all publications, Henriksen et al. was selected as the latest meta-analysis that best matched the inclusion and exclusion criteria [28]. This meta-analysis included eight randomized trials that investigated the role of TCS in preventing SSIs in adult patients undergoing gastrointestinal surgery [20-27]. In the pooled analysis, the authors found a significant reduction of SSIs in the experimental group (SSI rate $10.1 \%$ for TCS versus $13.5 \%$ for CS; OR: $0.67 ; 95 \%$ CI: $0.46-0.98 ; p=0.04$ ). Another meta-analysis, with similar characteristics that included 10 RCTs, published in 2018, was not considered due to an input mistake in the forest plot analysis of the TCS effect in gastrointestinal surgery [29]. In particular, for Diener et al. [21], the authors considered 334 patients in the TCS arm 
versus 331 in the control arm instead of 587 and 598 patients, respectively, as reported in the original publication, thus resulting in an unreliable overall treatment OR.

The characteristics of the studies included in the Henriksen et al. meta-analysis are summarized in Table 3. The heterogeneity among the RCTs was high: four trials $[20,23,26,27]$ encompassed only elective colorectal surgery, one [21] comprised all types of elective procedures through a midline laparotomy, another [22] included both elective and emergency laparotomies, another [24] evaluated only emergency surgery for fecal peritonitis, and the final study [25] analyzed only patients undergoing open appendectomy. The study sample size varied from 100 to 1185 patients; the role of laparoscopy was not clearly reported in the majority of studies.

Following publication of the above mentioned meta-analysis, two additional RCTs that investigated the role of TCS in abdominal surgery were identified [40,41]. Ichida et al. [41] evaluated 1013 adult patients undergoing both laparoscopic and open gastrointestinal operations; the authors declared full adherence to the WHO recommendations for SSI prevention. After a follow-up of 30 days, the study results showed no difference between the groups $(6.9 \%$ in the TCS group versus $5.9 \%$ in the control group; $p=0.609$ ). Furthermore, no significant differences within all subgroups were identified when comparing interventions for different target abdominal organs.

Olmez et al. [40] reported a RCT that investigated the effect of triclosan-coated monofilament polydioxanone (PDS) compared to standard PDS on SSI incidence after laparotomy for any type of gastrointestinal disease in 890 patients. The Consolidated Standards of Reporting Trials diagram of the randomization process and the concealment assignment were not available. The authors reported antibiotic prophylaxis as the only standard strategy for SSI prevention. Likewise, patients in the two study groups had significant differences in baseline characteristics (Body mass index, smoking habit, anemia, hypertension, and diabetes mellitus) that are potentially involved in SSI risk. The overall effect of TCS was a significant but untrustworthy reduction in the rate of SSI (19.1\% vs. $25.8 \%$ in the TCS and CS groups, respectively; $p=0.016$ ). 
Table 2. Meta-analyses reviewed.

\begin{tabular}{|c|c|c|c|c|c|c|}
\hline Study & N. studies & N. pts & Surgeries & Population & Publication Bias & $\begin{array}{l}\text { Results for Abdominal } \\
\text { Surgery and RCTs Only }\end{array}$ \\
\hline Wang et al. [42] & $17 \mathrm{RCTs}$ & $\begin{array}{c}3720 \\
\text { TCS:1726; CS:1994 }\end{array}$ & $\begin{array}{c}\text { Abdominal } \\
\text { Breast } \\
\text { Cardiovascular }\end{array}$ & $\begin{array}{l}\text { Adult (15 studies) } \\
\text { Pediatric ( } 2 \text { studies) }\end{array}$ & None & $\begin{array}{c}\mathrm{RR}=0.69 \\
95 \% \mathrm{CI}: 0.50-0.97 \\
p=0.03 ; \mathrm{I}^{2}=34 \%\end{array}$ \\
\hline Daoud et al. [34] & $15 \mathrm{RCTs}$ & $\begin{array}{c}4800 \\
\text { TCS: } 2323 ; \mathrm{CS}=2477\end{array}$ & $\begin{array}{c}\text { Neurosurgery } \\
\text { Abdominal/CR } \\
\text { Breast } \\
\text { Cardiovascular } \\
\text { Various } \\
\end{array}$ & $\begin{array}{l}\text { Adult (14) } \\
\text { Pediatric (3) }\end{array}$ & None & $\begin{array}{c}\mathrm{RR}=0.67 \\
95 \% \mathrm{CI}: 0.54-0.84 \\
p=0.00053 ; \mathrm{I}^{2}=\mathrm{N} / \mathrm{A}\end{array}$ \\
\hline Apisarnthanarak et al. [35] & $\begin{array}{c}29 \\
22 \text { RCTs } \\
7 \text { non-RCTs }\end{array}$ & $\begin{array}{c}11,942 \\
\text { TCS: 5,802; CS: 6,140 }\end{array}$ & $\begin{array}{c}\text { Neurosurgery } \\
\text { Abdominal/CR } \\
\text { Breast } \\
\text { Cardiovascular } \\
\text { Head/neck } \\
\text { Pelvic surgery } \\
\text { Various }\end{array}$ & NR & None & $\begin{array}{c}\text { RR: } 0.56 \\
95 \% \text { CI: } 0.41-0.77 \\
p<0.05 ; \mathrm{I}^{2}=64.6 \%\end{array}$ \\
\hline Guo et al. [36] & $13 \mathrm{RCTs}$ & $\begin{array}{c}5256 \\
\text { TCS: 2,592; CS: } 2592\end{array}$ & $\begin{array}{c}\text { Abdominal } \\
\text { Breast } \\
\text { Cardiovascular } \\
\text { Vascular } \\
\text { Various } \\
\end{array}$ & Adult & Low & $\begin{array}{c}\mathrm{RR}=0.70 \\
95 \% \text { CI: } 0.50-0.99 \\
p=0.04 ; \mathrm{I}^{2}=52 \%\end{array}$ \\
\hline Sandini et al. [37] & 6 RCTs & $\begin{array}{c}2168 \\
\text { TCS: 1,102; CS: } 1,066\end{array}$ & Colorectal & Adult & None & $\begin{array}{c}\mathrm{OR}=0.81 \\
95 \% \text { CI: } 0.58-1.13 \\
p=0.220 ; \mathrm{I}^{2}=44.9 \%\end{array}$ \\
\hline Elsolh et al. [38] & $5 \mathrm{RCTs}$ & 3117 & Abdominal & Adult & None & $\begin{array}{c}\text { OR }=0.79 \\
95 \% \text { CI: } 0.57-1.09 \\
p=0.15 ; I^{2}=44 \%\end{array}$ \\
\hline Konstantelias et al. [39] & $\begin{array}{c}30 \\
\text { RCTs: } 19 \\
\text { non-RCTs: } 11\end{array}$ & 15,385 & $\begin{array}{c}\text { Neurosurgery } \\
\text { Abdominal/CR } \\
\text { Breast } \\
\text { Cardiovascular } \\
\text { Head and neck } \\
\text { Spine } \\
\text { Various }\end{array}$ & NR & None & $\begin{array}{l}\text { RCTs: RR }=0.74 \\
95 \% \text { CI: } 0.44-1.27 \\
p=N S ; I^{2}=54 \%\end{array}$ \\
\hline Henriksen et al. [28] & 8 RCTs & $\begin{array}{c}3502 \\
\text { TCS: } 1,797 ; \text { CS: } 1,705\end{array}$ & Abdominal/CR & Adult & NR & $\begin{array}{c}\text { OR }=0.67 \\
95 \% \text { CI: } 0.46-0.98 \\
p=0.04 ; I^{2}=56 \%\end{array}$ \\
\hline Uchino et al. [29] & $\begin{array}{c}15 \\
\text { RCTs: } 10 \\
\text { non-RCTs: } 5\end{array}$ & $\begin{array}{c}5703 \\
\text { TCS: 2,889; CS: } 2,814\end{array}$ & Abdominal/CR & Adult & Minimal & $\begin{array}{l}\text { RCTs: } R R=0.67 \\
95 \% \text { CI: } 0.48-0.94 \\
p=0.02 ; I^{2}=55 \%\end{array}$ \\
\hline
\end{tabular}

Abbreviations: CR, colorectal; CS, conventional sutures; NR, not reported; RCT, randomized controlled trial; TCS, Triclosan-coated sutures; RR, risk ratio; and OR, odds ratio. Surgeries were reported if analyzed in sub-analysis (for meta-analyses performing sub-analyses). 
Table 3. Details of the randomized trials included in the Henriksen et al. meta-analysis.

\begin{tabular}{|c|c|c|c|c|c|c|c|}
\hline \multirow{2}{*}{ First Author } & \multirow{2}{*}{$\begin{array}{l}\mathbf{N}^{\circ} \text { of pts } \\
\text { (TCS/CS) }\end{array}$} & \multirow{2}{*}{ Type of Surgery } & \multirow{2}{*}{$\begin{array}{c}\text { Additional Preventive } \\
\text { Strategies for SSI }\end{array}$} & \multirow{2}{*}{ Follow-Up } & \multicolumn{3}{|c|}{ SSI Rates } \\
\hline & & & & & TCS & CS & $p$-Value \\
\hline Baracs et al. [20] & $\begin{array}{c}385 \\
(188 / 197)\end{array}$ & $\begin{array}{c}\text { Elective open } \\
\text { colorectal surgery }\end{array}$ & antibiotic prophylaxis & $\begin{array}{l}\text { Clinical examination } \\
\text { during hospital stay, } \\
\text { telephonic follow-up at } \\
30 \mathrm{~d}\end{array}$ & $12.2 \%$ & $12.2 \%$ & 0.98 \\
\hline Diener et al. [21] & $\begin{array}{c}1185 \\
(587 / 598)\end{array}$ & $\begin{array}{l}\text { Elective midline } \\
\text { laparotomies }\end{array}$ & $\begin{array}{l}\text { antibiotic prophylaxis } \\
\text { routine scrub } \\
\text { site preparation } \\
\end{array}$ & $\begin{array}{c}\text { Clinical examination at } \\
10 \text { and } 30 \mathrm{~d} \text { from } \\
\text { discharge }\end{array}$ & $14.8 \%$ & $16.1 \%$ & 0.64 \\
\hline Justinger et al. [22] & $\begin{array}{c}856 \\
(485 / 371)\end{array}$ & $\begin{array}{l}\text { Emergency or } \\
\text { elective } \\
\text { laparotomies }\end{array}$ & $\begin{array}{l}\text { bowel preparation } \\
\text { iodine shower } \\
\text { site preparation } \\
\text { antibiotic prophylaxis }\end{array}$ & $\begin{array}{c}\text { Clinical examination } \\
\text { during hospital stay and } \\
\text { at } 14 \mathrm{~d}\end{array}$ & $6.4 \%$ & $11.3 \%$ & $<0.05$ \\
\hline Mattavelli et al. [23] & $\begin{array}{c}281 \\
(140 / 141)\end{array}$ & $\begin{array}{l}\text { Elective open } \\
\text { colorectal surgery }\end{array}$ & $\begin{array}{c}\text { Hair removal, skin } \\
\text { disinfection, antibiotic } \\
\text { prophylaxis, prevention } \\
\text { of hypothermia }\end{array}$ & $\begin{array}{l}\text { Weekly examination } \\
\text { until } 30 \mathrm{~d} \text { from } \\
\text { discharge }\end{array}$ & $12.9 \%$ & $10.6 \%$ & 0.564 \\
\hline Mingmalairak et al. [25] & $\begin{array}{c}100 \\
(50 / 50) \\
\end{array}$ & $\begin{array}{c}\text { Open } \\
\text { appendectomy }\end{array}$ & Antibiotic prophylaxis & $\begin{array}{c}\text { Clinical examination at } \\
1,3,7,14,30 \mathrm{~d}\end{array}$ & $10 \%$ & $8 \%$ & 0.727 \\
\hline Nakamura et al. [26] & $\begin{array}{c}410 \\
(206 / 204)\end{array}$ & $\begin{array}{l}\text { Elective colorectal } \\
\text { surgery }\end{array}$ & $\begin{array}{l}\text { Antibiotic prophylaxis } \\
\text { and wound protector }\end{array}$ & $\begin{array}{l}\text { Daily during hospital } \\
\text { stay, weekly until } 30 \mathrm{~d} \\
\text { after discharge }\end{array}$ & $4.3 \%$ & $9.3 \%$ & 0.047 \\
\hline Rasic et al. [27] & $\begin{array}{c}184 \\
(91 / 93)\end{array}$ & $\begin{array}{c}\text { Elective colorectal } \\
\text { surgery }\end{array}$ & Antibiotic prophylaxis & $\begin{array}{l}\text { Clinical evaluation } \\
\text { during hospital stay }\end{array}$ & $4.3 \%$ & $13.2 \%$ & 0.039 \\
\hline Ruiz-Tovar et al. [24] & $\begin{array}{c}101 \\
(50 / 51)\end{array}$ & $\begin{array}{c}\text { Emergency } \\
\text { laparotomies for } \\
\text { fecal peritonitis }\end{array}$ & $\begin{array}{l}\text { Antibiotic prophylaxis } \\
\text { wound irrigation; } \\
\text { sterile-drape }\end{array}$ & $\begin{array}{l}\text { Clinical examination at } \\
5,30 \text { and } 60 \mathrm{~d}\end{array}$ & $10 \%$ & $35.3 \%$ & 0.004 \\
\hline
\end{tabular}

Abbreviations: ASA, American Society of Anesthesiologists; HIV, human immunodeficiency virus; and SSI, surgical site infection. 


\subsection{Economic Results}

\subsubsection{Base Case Analyses}

A 33\% reduction from the Henriksen et al. meta-analysis was used in the budget impact analysis (OR: $0.67 ; 0.46-0.98 ; p=0.04$ ), as established from the results of the literature review [28]. We considered that when the incidence of an outcome of interest was common $(>10 \%)$, the adjusted OR that was derived from the logistic regression could no longer approximate the risk ratio. We therefore approximated a risk ratio from an adjusted OR ratio and derived an estimate of an SSI reduction that better represented the true RR [43]. The obtained RR (95\% CI) was 0.70 (0.49-0.98), and, accordingly, a $30 \%$ SSI reduction for TCS introduction was used in the model.

The budget impact analysis estimated an additional annual cost of $€ 600$ for a complete conversion of CS to TCS. TCS reduced the number of SSIs by $30 \%$, which led to the avoidance of 3.2 SSIs-over 100 surgeries performed-and associated hospital resources totaling $€ 15,385$ ( $€ 13,230$ for additional LOS and $€ 2155$ for additional resource use). The use of TCS resulted in an overall annual net saving of $€ 14,785$. The additional $€ 600$ associated with using TCS compared with CS were offset by the SSI reduction. The model also calculated the minimal SSI reduction required to cancel out the incremental cost of TCS: The additional cost of $€ 600$ for advancing wound closure technology was offset by an SSI reduction rate of approximately $1.2 \%$, equaling less than a single avoided SSI ( 0.1 episodes).

\subsubsection{Scenario and Sensitivity Analyses}

When assuming an SSI reduction rate of $2 \%$, the economic model resulted in an overall annual net saving of $€ 426$. In this scenario, 0.2 SSI episodes were avoided, thus accounting for a saving of $€ 1026$. The incremental expenditure of $€ 600$ was offset by the SSI reduction risk. Conversely, when the SSI reduction was set at $51 \%$, the annual net saving for the hospital was $€ 25,554$ with 5.4 SSI avoided episodes accounting for $€ 26,154$ of hospital resources.

The results of the one-way sensitivity analysis, represented as a tornado chart, are presented in Figure 1. The variables with the greatest influence on the annual savings in the model were related to efficacy parameters (SSI risk reduction and baseline SSI rate), with other parameters that were related to cost events found to demonstrate a minor influence on the annual savings. The annual savings remained positive across a broad variation in the ranges for each parameter.

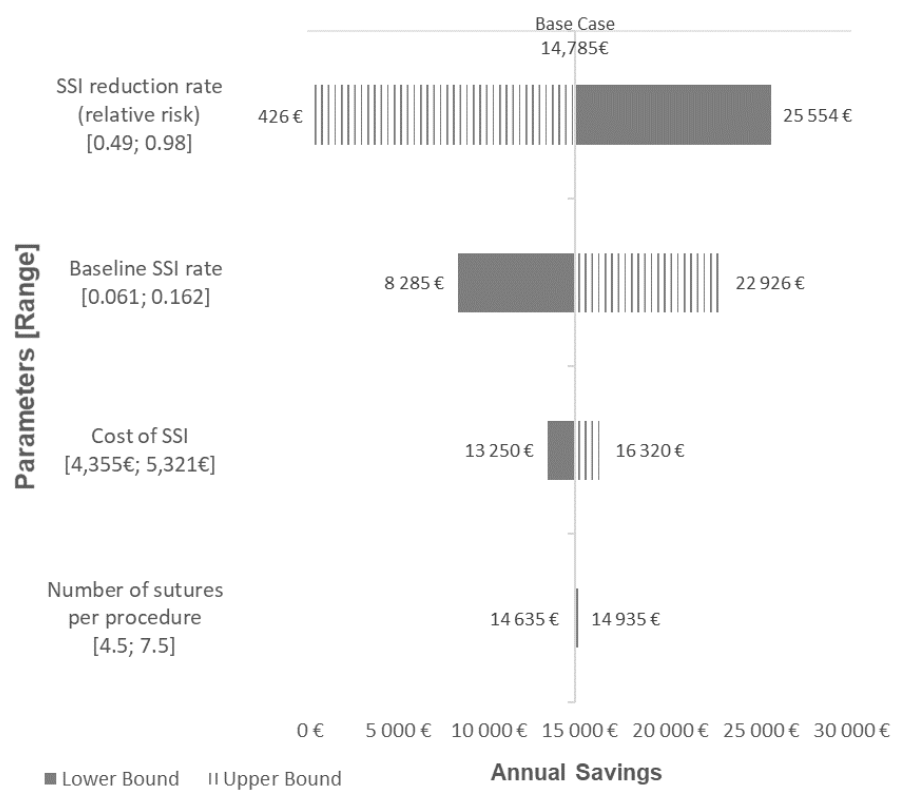

Figure 1. Tornado diagram with one-way sensitivity analysis results. Abbreviations: SSI, surgical site infection. 
The results of 1000 Monte-Carlo simulations of the annual savings are presented in Figure 2, and the number of avoided SSIs, based on PSA, are presented in Figure 3. The analysis demonstrated that the reduction of SSI episodes due to TCS ranged between 1 and 6 cases in $90 \%$ of the simulations. The mean (interquartile range (IQR)) annual savings that were obtained from the PSA was $€ 13,935$ $(9068-18,665)$. The whiskers extended the IQR by 1.5 to a maximum of $€ 32,369$ and a minimum of $-€ 4987$. The analysis demonstrated a $98 \%$ probability of TCS being cost saving, based on the assumptions made.

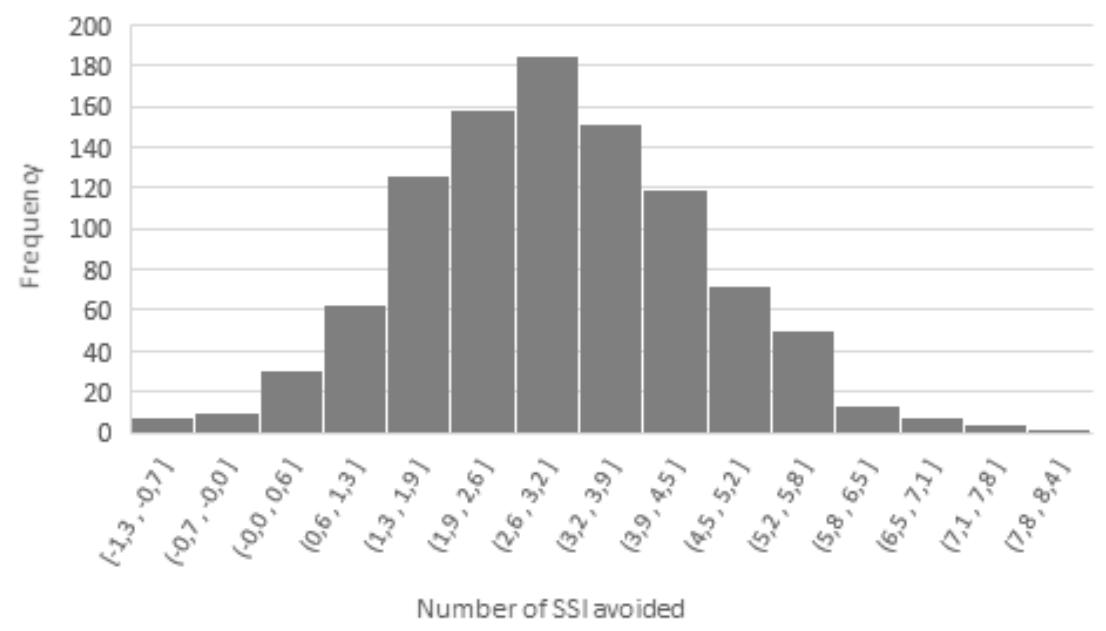

Figure 2. Histogram of the number of avoided SSI episodes according the probabilistic sensitivity analysis. Abbreviations: SSI, surgical site infection.

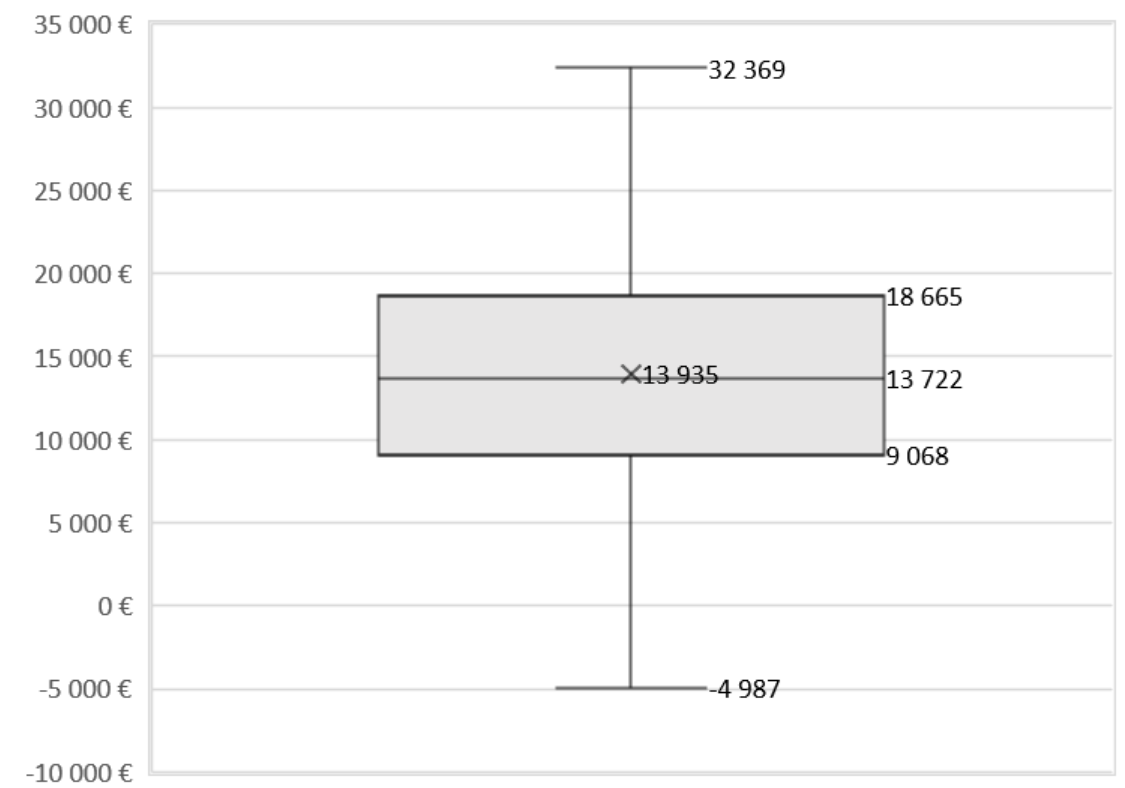

Figure 3. Boxplot of the annual budget impact (savings) according to the probabilistic sensitivity analysis.

\section{Discussion}

SSIs primarily result from the disruption of the equilibrium between the quantity of inoculated microorganisms, their virulence, and the ability of the immune system to clear them. TCS, which are coated in a broad-spectrum antimicrobial agent, reduce the bacterial load at the wound site, thereby potentially helping to reduce the risk of SSIs.

Meta-analysis is a useful tool in that it allows for data pooling from multiple trials and thus provides a more comprehensive estimation of treatment effects. However, this approach only partially restricted the confounding effect of the differences and heterogeneity among the included studies 
and populations. Among the available meta-analyses and in accordance with the defined inclusion criteria, we assessed and estimated the results of the 2017 meta-analysis reported by Henriksen et al. [28] as the most recently available evidence that fulfilled our clinical focus. The authors included all RCTs that evaluated the effect of TCS in patients who underwent abdominal surgery. The effect of TCS was evaluated in several studies that enrolled subjects with distinct patient-related and operation-related risk factors. There was heterogeneity between trials in terms of surgery type which included elective colorectal surgeries, elective procedures through midline laparotomy, elective and emergency laparotomies for any type of target organ, emergency surgery for fecal peritonitis, and open appendectomy. The pooled results yielded a significant 33\% reduction in the odds of having an SSI after surgery for patients who received a wound closure with TCS versus CS. However, it should be noted that intervention type (elective versus emergency), target organs, and the lack of implementation of recognized peri-operative strategies to reduce SSI likely limit the ability to define the true effect of TCS, adding high heterogeneity and possible confounders. Two additional RCTs $[40,41]$ that were published afterwards did not contribute to solving these uncertainties.

The effect of TCS should, ideally, be evaluated in a population with a fixed risk of SSI and, importantly, in a setting where all the WHO recommendations [16] (Table 4) are fulfilled to assess the true "over the top" protective effect of this strategy. The heterogeneity of studies' settings in terms of adherence to SSI prevention guidelines can therefore be considered as an additional bias; however, these limitations notwithstanding, all nine published meta-analyses reported a consistent decrease in the risk of having an SSI with the use of the used TCS (Table 2). Despite the fact that some of the available meta-analyses did not demonstrate significant differences compared to the control arms, the decrease in the SSI rate can still be considered important as it may result in a net financial saving even if the cost of TCS is higher than CS.

Table 4. World Health Organization recommendations for SSI prevention, 2016 version.

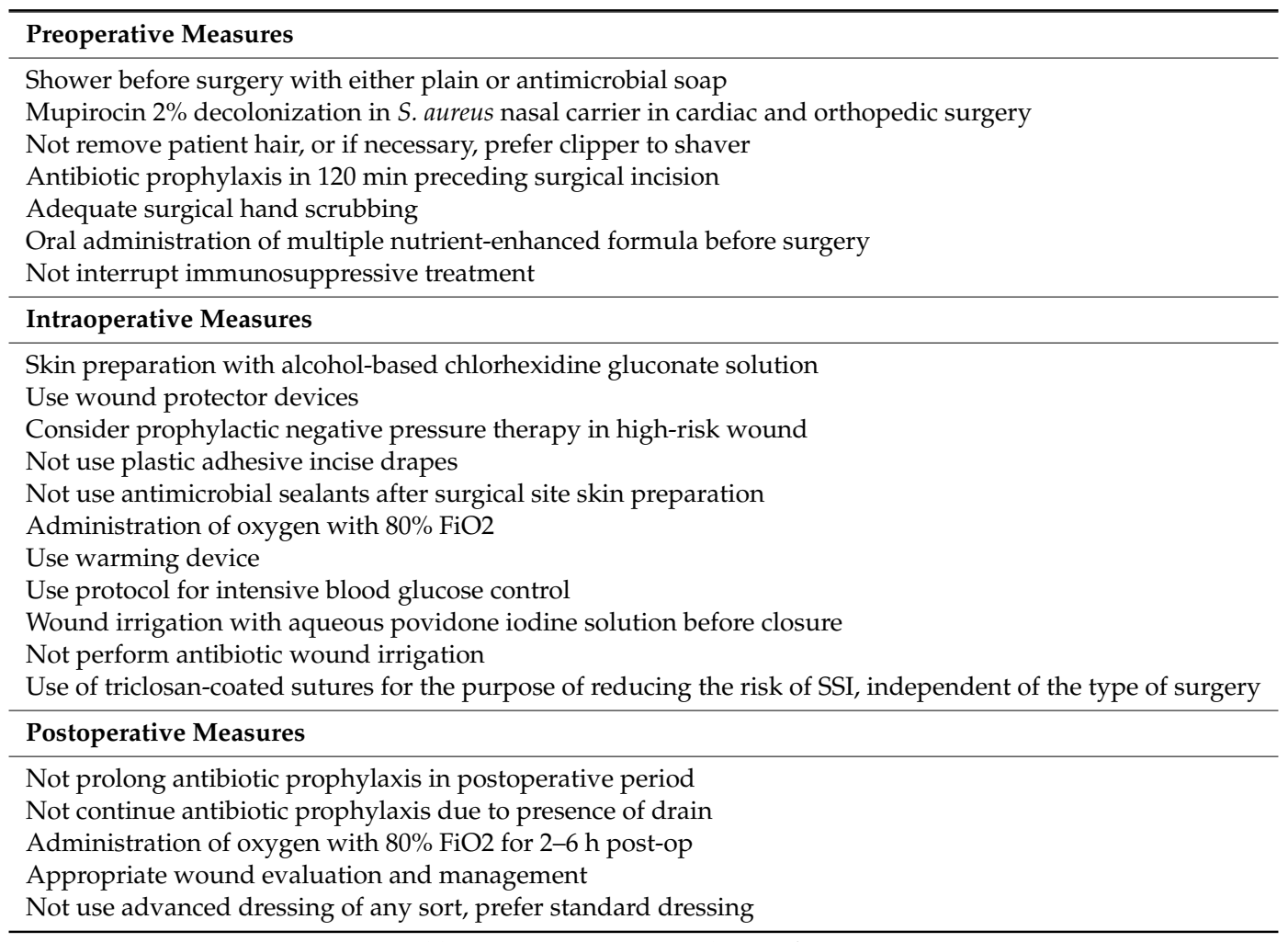

Abbreviations: SSI, surgical site infection. 
A budget impact analysis was performed to evaluate the economic impact of adopting TCS into clinical practice from the perspective of a general surgery unit in an Italian hospital. The model demonstrated that the incremental cost of adopting TCS was offset by the cost of SSI episodes that were avoided. Despite an upfront incremental acquisition cost of $€ 600$, the use of TCS resulted in an overall annual net saving of $€ 14,785$ for the institution. Furthermore, sensitivity analyses demonstrated that, across a broad variation in the ranges for each parameter, the annual savings remained positive with a $98 \%$ probability that TCS was cost-saving.

Leaper et al. [44], by using a deterministic decision-tree, a stochastic cost model, and the National Health Service (NHS England)-based cost of inpatient admissions for infections and differential costs of TCS versus CS, estimated a significant mean saving of $£ 91.25$ per surgical procedure from using antimicrobial sutures across all surgical wound types. This is aligned with the findings in this analysis, where the overall saving was split for single hospitalization with a saving of $€ 147.85$. This was further supported by three trials that were published between 2007 and 2013 that evaluated the clinical efficacy and economic impact of TCS and which demonstrated a net economic saving resulting from adopting TCS rather than CS $[26,45,46]$.

The relevance of this study to the Italian healthcare system lies in the use of Italian-specific input data for SSI risk and SSI cost. This analysis could therefore be valuable to support decision-making processes at the hospital level in Italy. The robustness of the model is increased by the performed sensitivity analyses; however, the limitations of the model lie in some of the inputs being extrapolated from literature research, not being real-world data, or being inflated to current values from outdated data like the SSI cost. To alleviate this, additional analyses, based on recent real-world data from one or more Italian hospitals could be performed to demonstrate the real budget impact of adopting TCS into Italian clinical practice.

Hence, in the decision-making process to adopt a new technology or device, a robust economic analysis should always couple the clinical results to gather additional and essential information on the potential dominant cost-effectiveness ratio.

\section{Conclusions}

This critical review provides an overview of the available evidence on the role of TCS in preventing SSI in patients undergoing abdominal surgery, and it reports the economic impact of adopting TCS into clinical practice. The results did not completely rule out and solve the conflicting results in the literature on the clinical benefit of TCS on the prevention of wound infection. However, the economic cost model that was used in this study found that the use of TCS results in significant and robust cost saving from the perspective of an Italian hospital that performs abdominal operations. The results might be transferred to many other different hypothetical settings. Triclosan antimicrobial surgical sutures should be considered for wound closure as a cost-saving measure to prevent SSIs.

Author Contributions: Conceptualization, A.P., T.G., V.P., L.G., G.A.T., F.C. and M.C.; methodology, A.P., T.G., L.G., V.P., G.A.T., F.C. and M.C.; software, A.P., T.G.; validation, A.P., T.G., V.P., L.G., G.A.T., F.C. and M.C.; formal analysis, A.P., T.G., V.P. and L.G.; writing, A.P., T.G., V.P., L.G., G.A.T., F.C. and M.C.; visualization, T.G.; supervision, G.A.T. and L.G. All authors have read and agreed to the published version of the manuscript.

Funding: Johnson and Johnson funded medical writing services for this research. The authors received no financial support for the research, authorship, and publication of this article.

Acknowledgments: We thank James Woolnough and Roderick Walker (Mtech) for medical writing support.

Conflicts of Interest: Alessandra Piemontese, Giovanni Tommaselli, Thibaut Galvain and Vito Parago all declare to be employees of Johnson \& Johnson. 


\section{Appendix A}

Table A1. Meta-analyses published between January 1990 and June 2019 not included in the study results.

\begin{tabular}{|c|c|c|c|c|}
\hline Study & $\begin{array}{c}\text { Publication } \\
\text { Year }\end{array}$ & $\begin{array}{l}\text { N. Studies/ } \\
\text { N. Pts }\end{array}$ & $\begin{array}{l}\text { Results for all Surgery } \\
\text { and Study Type }\end{array}$ & $\begin{array}{l}\text { Reason for } \\
\text { Exclusion }\end{array}$ \\
\hline Chang et al. & 2012 & $\begin{array}{l}7 \mathrm{RCTs} \\
836 \text { pts }\end{array}$ & $\begin{array}{c}\text { OR }=0.77 \\
95 \% \text { CI: } 0.40-1.51 \\
p=0.45\end{array}$ & $\begin{array}{c}\text { All surgery types } \\
\text { No abdominal } \\
\text { surgery results }\end{array}$ \\
\hline Sajid et al. & 2013 & $\begin{array}{l}7 \mathrm{RCTs} \\
1631 \text { pts }\end{array}$ & $\begin{array}{c}\mathrm{RR}=0.61 \\
95 \% \mathrm{CI}: 0.37-0.99 \\
p=0.04\end{array}$ & $\begin{array}{l}\text { All surgery types } \\
\text { No abdominal } \\
\text { surgery results }\end{array}$ \\
\hline $\begin{array}{l}\text { Edmiston et } \\
\text { al. }\end{array}$ & 2013 & $\begin{array}{l}13 \mathrm{RCTs} \\
3568 \text { pts }\end{array}$ & $\begin{array}{c}\mathrm{RR}=0.734 \\
95 \% \text { CI: } 0.590-0.913 \\
p=0.005\end{array}$ & $\begin{array}{l}\text { All surgery types } \\
\text { No abdominal } \\
\text { surgery results }\end{array}$ \\
\hline Wu et al. & 2017 & $\begin{array}{c}18 \\
13 \mathrm{RCTs} \\
5 \text { non-RCTs } \\
7458 \text { pts }\end{array}$ & $\begin{array}{c}\text { RCTs: OR }=0.72 \\
95 \% \text { CI: } 0.59-0.88 \\
p=0.001 \\
\text { Non-RCTs: OR }=0.58 \\
95 \% \text { CI: } 0.40-0.83 \\
p=0.003\end{array}$ & $\begin{array}{l}\text { All surgery types } \\
\text { No abdominal } \\
\text { surgery results }\end{array}$ \\
\hline de Jonge et al. & 2017 & $\begin{array}{l}21 \mathrm{RCTs} \\
6462 \text { pts }\end{array}$ & $\begin{array}{c}\mathrm{RR}=0.72 \\
95 \% \mathrm{CI}: 0.60-0.86 \\
P<0.001\end{array}$ & $\begin{array}{l}\text { All surgery types } \\
\text { No abdominal } \\
\text { surgery results }\end{array}$ \\
\hline Leaper et al. & 2017 & $\begin{array}{c}34 \\
20 \mathrm{RCTs} \\
14 \text { non-RCTs } \\
\text { NR pts }\end{array}$ & $\begin{array}{c}\text { OR }=0.61 \\
95 \% \text { CI: } 0.52-0.73 \\
P<0.001\end{array}$ & $\begin{array}{l}\text { All surgery types } \\
\text { No abdominal } \\
\text { surgery results } \\
\text { No RCTs results }\end{array}$ \\
\hline Hunger et al. & 2018 & $\begin{array}{c}6 \\
3 \text { RCTs } \\
3 \text { non-RCTs } \\
5188 \text { pts }\end{array}$ & $\begin{array}{c}\text { RCTs: RR }=0.67 \\
\text { 95\% CI: } 0.48-0.94 \\
p=0.02 \\
\text { Non-RCTs: OR }=0.4 \\
\text { 95\% CI: } 0.3-0.54 \\
P<0.001\end{array}$ & $\begin{array}{l}\text { All surgery types } \\
\text { No abdominal } \\
\text { surgery results }\end{array}$ \\
\hline
\end{tabular}

Abbreviations: NR, not reported; RCT, randomized controlled trial.

\section{References}

1. European Centre for Disease Prevention and Control. Surveillance of Surgical Site Infections and Prevention Indicators in European Hospitals: HAI-Net SSI Protocol; Version 2.2; Tommi Kärki: Carl Suetens, Stockholm, May 2017; ISBN 978-92-9498-060-1.

2. Preventing Surgical Site Infections: Implementation Approaches for Evidence-Based Recommendations. World Health Organization: Geneva, 2018. Licence: CC BYNC-SA 3.0 IGO. Available online: https: //apps.who.int/iris/bitstream/handle/10665/273154/9789241514385-eng.pdf (accessed on 1 August 2019).

3. Aga, E.; Keinan-Boker, L.; Eithan, A.; Mais, T.; Rabinovich, A.; Nassar, F. Surgical site infections after abdominal surgery: Incidence and risk factors. A prospective cohort study. Infect. Dis. 2015, 47, 761-767. [CrossRef] [PubMed]

4. Veljkovic, R.; Protic, M.; Gluhovic, A.; Potic, Z.; Milosevic, Z.; Stojadinovic, A. Prospective clinical trial of factors predicting the early development of incisional hernia after midline laparotomy. J. Am. Coll. Surg. 2010, 210, 210-219. [CrossRef]

5. Murray, B.W.; Cipher, D.J.; Pham, T.; Anthony, T. The impact of surgical site infection on the development of incisional hernia and small bowel obstruction in colorectal surgery. Am. J. Surg. 2011, 202, 558-560. [CrossRef] [PubMed] 
6. Badia, J.M.; Casey, A.L.; Petrosillo, N.; Hudson, P.M.; Mitchell, S.A.; Crosby, C. Impact of surgical site infection on healthcare costs and patient outcomes: A systematic review in six European countries. J. Hosp. Infect. 2017, 96, 1-15. [CrossRef] [PubMed]

7. O'Brien, W.J.; Gupta, K.; Itani, K.M.F. Association of Postoprative infection With Risk of Long-term Infection and Mortality. JAMA Surg. 2020, 155, 61-68. [CrossRef] [PubMed]

8. Nespoli, A.; Gianotti, L.; Totis, M.; Bovo, G.; Nespoli, L.; Chiodini, P.; Brivio, F. Correlation between postoperative infections and long-term survival after colorectal resection for cancer. Tumori 2004, 90, 485-490. [CrossRef] [PubMed]

9. Chuah, L.L.; Papamargaritis, D.; Pillai, D.; Krishnamoorthy, A.; le Roux, C.W. Morbidity and mortality of diabetes with surgery. Nutr. Hosp. 2013, 28, 47-52.

10. Sørensen, L.T.; Hemmingsen, U.; Kallehave, F.; Wille-Jørgensen, P.; Kjærgaard, J.; Møller, L.N.; Jørgensen, T. Risk Factors for Tissue and Wound Complications in Gastrointestinal Surgery. Ann. Surg. 2005, 241, $654-658$. [CrossRef]

11. Dobner, J.; Kaser, S. Body mass index and the risk of infection - from underweight to obesity. Clin. Microbiol. Infect. 2018, 24, 24-28. [CrossRef]

12. Thelwall, S.; Harrington, P.; Sheridan, E.; Lamagni, T. Impact of obesity on the risk of wound infection following surgery: Results from a nationwide prospective multicentre cohort study in England. Clin. Microbiol. Infect. 2015, 21, 1008.e1-1008.e8. [CrossRef]

13. Alexander, J.W.; Kaplan, J.Z.; Altemeier, W.A. Role of suture materials in the development of wound infection. Ann. Surg. 1967, 165, 192-199. [CrossRef]

14. Kampf, G.; Kramer, A. Epidemiologic background of hand hygiene and evaluation of the most important agents for scrubs and rubs. Clin. Microbiol. Rev. 2004, 17, 863-893. [CrossRef] [PubMed]

15. Leaper, D.; Assadian, O.; Hubner, N.-O.; McBain, A.; Barbolt, T.; Rothenburger, S.; Wilson, P. Antimicrobial sutures and prevention of surgical site infection: Assessment of the safety of the antiseptic triclosan. Int. Wound J. 2011, 8, 556-566. [CrossRef] [PubMed]

16. Global Guidelines for the Prevention of Surgical Site Infection, second edition. World Health Organization: Geneva, 2018. Licence: CC BY-NC-SA 3.0 IGO. Available online: https://apps.who.int/iris/bitstream/handle/ 10665/277399/9789241550475-eng.pdf?ua=1 (accessed on 1 August 2019).

17. Ban, K.A.; Minei, J.P.; Laronga, C.; Harbrecht, B.G.; Jensen, E.H.; Fry, D.E.; Itani, K.M.F.; Dellinger, E.P.; Ko, C.Y.; Duane, T.M. American College of Surgeons and Surgical Infection Society: Surgical Site Infection Guidelines, 2016 Update. J. Am. Coll. Surg. 2017, 224, 59-74. [CrossRef] [PubMed]

18. Berríos-Torres, S.I.; Umscheid, C.A.; Bratzler, D.W.; Leas, B.; Stone, E.C.; Kelz, R.R.; Reinke, C.E.; Morgan, S.; Solomkin, J.S.; Mazuski, J.E.; et al. Centers for Disease Control and Prevention Guideline for the Prevention of Surgical Site Infection, 2017. JAMA Surg. 2017, 152, 784-791. [CrossRef] [PubMed]

19. Surgical Site Infections: Prevention and Treatment NICE Guideline [NG125]. Available online: https: //www.nice.org.uk/guidance/ng125 (accessed on 1 August 2019).

20. Baracs, J.; Huszár, O.; Sajjadi, S.G.; Horváth, O.P. Surgical site infections after abdominal closure in colorectal surgery using triclosan-coated absorbable suture (PDS Plus) vs. uncoated sutures (PDS II): A randomized multicenter study. Surg. Infect. 2011, 12, 483-489. [CrossRef] [PubMed]

21. Diener, M.K.; Knebel, P.; Kieser, M.; Schüler, P.; Schiergens, T.S.; Atanassov, V.; Neudecker, J.; Stein, E.; Thielemann, H.; Kunz, R.; et al. Effectiveness of triclosan-coated PDS Plus versus uncoated PDS II sutures for prevention of surgical site infection after abdominal wall closure: The randomised controlled PROUD trial. Lancet 2014, 384, 142-152. [CrossRef]

22. Justinger, C.; Slotta, J.E.; Ningel, S.; Gräber, S.; Kollmar, O.; Schilling, M.K. Surgical-site infection after abdominal wall closure with triclosan-impregnated polydioxanone sutures: Results of a randomized clinical pathway facilitated trial (NCT00998907). Surgery 2013, 154, 589-595. [CrossRef]

23. Mattavelli, I.; Rebora, P.; Doglietto, G.; Dionigi, P.; Dominioni, L.; Luperto, M.; La Porta, A.; Garancini, M.; Nespoli, L.; Alfieri, S.; et al. Multi-Center Randomized Controlled Trial on the Effect of Triclosan-Coated Sutures on Surgical Site Infection after Colorectal Surgery. Surg. Infect. 2015, 16, 226-235. [CrossRef]

24. Ruiz-Tovar, J.; Alonso, N.; Morales, V.; Llavero, C. Association between Triclosan-Coated Sutures for Abdominal Wall Closure and Incisional Surgical Site Infection after Open Surgery in Patients Presenting with Fecal Peritonitis: A Randomized Clinical Trial. Surg. Infect. 2015, 16, 588-594. [CrossRef] 
25. Mingmalairak, C.; Ungbhakorn, P.; Paocharoen, V. Efficacy of antimicrobial coating suture coated polyglactin 910 with tricosan (Vicryl plus) compared with polyglactin 910 (Vicryl) in reduced surgical site infection of appendicitis, double blind randomized control trial, preliminary safety report. J. Med. Assoc. Thai. 2009, 92, 770-775. [PubMed]

26. Nakamura, T.; Kashimura, N.; Noji, T.; Suzuki, O.; Ambo, Y.; Nakamura, F.; Kishida, A. Triclosan-coated sutures reduce the incidence of wound infections and the costs after colorectal surgery: A randomized controlled trial. Surgery 2013, 153, 576-583. [CrossRef]

27. Rasić, Z.; Schwarz, D.; Adam, V.N.; Sever, M.; Lojo, N.; Rasić, D.; Matejić, T. Efficacy of antimicrobial triclosan-coated polyglactin 910 (Vicryl* Plus) suture for closure of the abdominal wall after colorectal surgery. Coll. Antropol. 2011, 35, 439-443. [PubMed]

28. Henriksen, N.A.; Deerenberg, E.B.; Venclauskas, L.; Fortelny, R.H.; Garcia-Alamino, J.M.; Miserez, M.; Muysoms, F.E. Triclosan-coated sutures and surgical site infection in abdominal surgery: The TRISTAN review, meta-analysis and trial sequential analysis. Hernia 2017, 21, 833-841. [CrossRef] [PubMed]

29. Uchino, M.; Mizuguchi, T.; Ohge, H.; Haji, S.; Shimizu, J.; Mohri, Y.; Yamashita, C.; Kitagawa, Y.; Suzuki, K.; Kobayashi, M.; et al. The Efficacy of Antimicrobial-Coated Sutures for Preventing Incisional Surgical Site Infections in Digestive Surgery: A Systematic Review and Meta-analysis. J. Gastrointest. Surg. 2018, 22, 1832-1841. [CrossRef] [PubMed]

30. Mauskopf, J.A.; Sullivan, S.D.; Annemans, L.; Caro, J.; Mullins, C.D.; Nuijten, M.; Orlewska, E.; Watkins, J.; Trueman, P. Principles of good practice for budget impact analysis: Report of the ISPOR Task Force on good research practices-budget impact analysis. Value Health 2007, 10, 336-347. [CrossRef] [PubMed]

31. Sullivan, S.D.; Mauskopf, J.A.; Augustovski, F.; Jaime Caro, J.; Lee, K.M.; Minchin, M.; Orlewska, E.; Penna, P.; Rodriguez Barrios, J.-M.; Shau, W.-Y. Budget impact analysis-principles of good practice: Report of the ISPOR 2012 Budget Impact Analysis Good Practice II Task Force. Value Health 2014, 17, 5-14. [CrossRef]

32. Gianotti, L.; Braga, M.; Frei, A.; Greiner, R.; Di Carlo, V. Health care resources consumed to treat postoperative infections: Cost saving by perioperative immunonutrition. Shock 2000, 14, 325-330. [CrossRef]

33. Wang, G.J.; Hungerford, D.S.; Savory, C.G.; Rosenberg, A.G.; Mont, M.A.; Burks, S.G.; Mayers, S.L.; Spotnitz, W.D. Use of fibrin sealant to reduce bloody drainage and hemoglobin loss after total knee arthroplasty: A brief note on a randomized prospective trial. J. Bone Jt. Surg. Am. 2001, 83, 1503-1505. [CrossRef]

34. Daoud, F.C.; Edmiston, C.E.; Leaper, D. Meta-analysis of prevention of surgical site infections following incision closure with triclosan-coated sutures: Robustness to new evidence. Surg. Infect. 2014, 15, 165-181. [CrossRef]

35. Apisarnthanarak, A.; Singh, N.; Bandong, A.N.; Madriaga, G. Triclosan-coated sutures reduce the risk of surgical site infections: A systematic review and meta-analysis. Infect. Control. Hosp. Epidemiol. 2015, 36, 169-179. [CrossRef]

36. Guo, J.; Pan, L.-H.; Li, Y.-X.; Yang, X.-D.; Li, L.-Q.; Zhang, C.-Y.; Zhong, J.-H. Efficacy of triclosan-coated sutures for reducing risk of surgical site infection in adults: A meta-analysis of randomized clinical trials. $J$. Surg. Res. 2016, 201, 105-117. [CrossRef]

37. Sandini, M.; Mattavelli, I.; Nespoli, L.; Uggeri, F.; Gianotti, L. Systematic review and meta-analysis of sutures coated with triclosan for the prevention of surgical site infection after elective colorectal surgery according to the PRISMA statement. Medicine 2016, 95, e4057. [CrossRef] [PubMed]

38. Elsolh, B.; Zhang, L.; Patel, S.V. The Effect of Antibiotic-Coated Sutures on the Incidence of Surgical Site Infections in Abdominal Closures: A Meta-Analysis. J. Gastrointest. Surg. 2017, 21, 896-903. [CrossRef] [PubMed]

39. Konstantelias, A.A.; Andriakopoulou, C.S.I.; Mourgela, S. Triclosan-coated sutures for the prevention of surgical-site infections: A meta-analysis. Acta Chir. Belg. 2017, 117, 137-148. [CrossRef] [PubMed]

40. Olmez, T.; Berkesoglu, M.; Turkmenoglu, O.; Colak, T. Effect of Triclosan-Coated Suture on Surgical Site Infection of Abdominal Fascial Closures. Surg. Infect. 2019, 20, 658-664. [CrossRef] [PubMed]

41. Ichida, K.; Noda, H.; Kikugawa, R.; Hasegawa, F.; Obitsu, T.; Ishioka, D.; Fukuda, R.; Yoshizawa, A.; Tsujinaka, S.; Rikiyama, T. Effect of triclosan-coated sutures on the incidence of surgical site infection after abdominal wall closure in gastroenterological surgery: A double-blind, randomized controlled trial in a single center. Surgery 2018. [CrossRef] 
42. Wang, Z.X.; Jiang, C.P.; Cao, Y.; Ding, Y.T. Systematic review and meta-analysis of triclosan-coated sutures for the prevention of surgical-site infection. Br. J. Surg. 2013, 100, 465-473. [CrossRef]

43. Zhang, J.; Yu, K.F. What's the relative risk? A method of correcting the odds ratio in cohort studies of common outcomes. JAMA 1998, 280, 1690-1691. [CrossRef]

44. Leaper, D.J.; Edmiston, C.E.; Holy, C.E. Meta-analysis of the potential economic impact following introduction of absorbable antimicrobial sutures. Br. J. Surg. 2017, 104, e134-e144. [CrossRef]

45. Galal, I.; El-Hindawy, K. Impact of using triclosan-antibacterial sutures on incidence of surgical site infection. Am. J. Surg. 2011, 202, 133-138. [CrossRef] [PubMed]

46. Fleck, T.; Moidl, R.; Blacky, A.; Fleck, M.; Wolner, E.; Grabenwoger, M.; Wisser, W. Triclosan-coated sutures for the reduction of sternal wound infections: Economic considerations. Ann. Thorac. Surg. 2007, 84, 232-236. [CrossRef] [PubMed]

(C) 2020 by the authors. Licensee MDPI, Basel, Switzerland. This article is an open access article distributed under the terms and conditions of the Creative Commons Attribution (CC BY) license (http://creativecommons.org/licenses/by/4.0/). 